\title{
Vårt bilde av Russland - 25 debattinnlegg om naboskap i nord
}

Lars Rowe, Jørgen Holten Jørgensen \& Geir Hønneland

Bergen: John Grieg Forlag 2015

128 sider. ISBN: 9788253303345

Anmeldt av Anja Kristine Salo [kommunikasjonsansvarlig i Barentssekretariatet, Kirkenes, anja@barents.no]

Vårt bilde av Russland, med sine analyser og betraktninger, er høyaktuell for å forstå Norges forhold til Russland i en krevende tid. Dessverre skjemmes boka av for mange gjentakelser.

Da jeg flyttet til Kirkenes for fire år siden var det eufori i det norsk-russiske samarbeidet. Landene hadde nettopp blitt enige om delelinjen i Barentshavet og statsminister Dmítrij Medvédev var i Kirkenes for å feire 20 år med Barentssamarbeid. Med den folkerettsstridige annekteringen av Krim i 2014 snudde dette. Fra å snakke om at samarbeidet mellom Norge og Russland aldri har vært bedre, er mantraet nå at Norge er det eneste nabolandet Russland ikke har vært i krig med. Det bilaterale forholdet har ikke vært under større press siden den kalde krigen.

Forfatterne av Vårt bilde av Russland er alle russlandsforskere ved Fridtjof Nansens Institutt og flere av dem har bodd og arbeidet med Russland i vårt nordligste fylke Finnmark. De kjenner derfor saksfeltet godt og setter dagens hendelser inn $\mathrm{i}$ en historisk og politisk kontekst. Boka består av 25 debattinnlegg forfatterne har hatt på trykk i norske aviser fra 2007 til 2015.

I denne perioden har vi både sett en positiv utvikling i det norsk-russiske samarbeidet, men kanskje desto større tilbakeskritt. I Vesten så man på valget av president Dmítrij Medvédev i 2008 som et signal på at Russland var på vei i en mer demokratisk og liberal retning. Isolert sett stemmer dette i en norsk-russisk kontekst. Det var nettopp i denne perioden Norge og Russland kom fram til en endelig delelinjeavtale i Barentshavet og man fikk visumfrie soner på både norsk og russisk side av grensen i nord. Fra 2012, da Vladímir Pútin ble gjeninnsatt som president, og fram til i dag, har vi sett et stadig mer autoritært og innadvendt Russland, som ikke går av veien for å bryte internasjonale avtaler. Til tross for det, som forfatterne av boka sier:

«Norge er fremdeles Russlands nabo, og dermed også et land den norske regjeringen med underliggende etater må forholde seg konstruktivt og fornuftig til. Kronikkene er et forsøk på å bidra til at dette kan skje» (s. 16).

I første del av boka presenteres vi for den politiske utviklingen i Russland, mens forfatterne i del to mer spesifikt tar for seg sentrale saksfelt i det bilaterale forholdet, 
spesielt Barentshavet og Svalbard. Avslutningsvis blir vi gjort kjent med det russiske selvbildet og hvordan Russland ser på andre stater. Tematikken passer godt inn i dagens nyhetsbilde. Forfatterne analyserer både visestatsminister Dmítrij Rogózin uanmeldte Svalbard-besøk i april 2015 og bakgrunnen for annekteringen av Krim.

For mange i Vesten kom det som en stor overraskelse at Russland brøt folkeretten og annekterte en del av et naboland slik de gjorde i 2014. For den menige russer, derimot, representerer Krim et etterlengtet comeback på den internasjonale arenaen, som likeverdig part, etter å ha ligget med brukket rygg siden Sovjetunionens fall. Gjennom konkrete eksempler blir vi som lesere gjort oppmerksom på at det Vesten oppfatter som uforutsigbare handlinger, egentlig føyer seg inn i en kjent russisk tradisjon: «Russisk selvhevdelse er en like naturlig del av internasjonal politikk som andre stormakters maktutøvelse er det» (s. 39).

Selv om mange nok hadde håpet at Russland skulle utvikle seg $\mathrm{i}$ en mer demokratisk retning, er de autoritære trekkene vi nå er vitne til en tilbakevending til normaltilstanden, ifølge forfatterne. Rowe (s. 38) skriver eksempelvis at:

«Det er normalt for Russland å hevde sin rett til å øve innflytelse på nabostater som Georgia og Estland, og det er normalt for Russland å kontrollere meningsytringer innenfor egne grenser.»

I kapittelet om Barentshavet og Svalbard får vi viktig innsikt i Svalbardtraktaten og hvilke begrensinger som ligger i Norges myndighetsutøvelse her. Selv om Norge har suverenitet over Svalbard, har alle land fri adgang til øygruppen. Det betyr at visestatsminister Rogózin, som står på EU og Norges sanksjonsliste for sin rolle $\mathrm{i}$ Ukraina-krisen, i realiteten ikke utfordret norsk suverenitet da han landet på Svalbard i 2015.

Norske myndigheter reagerte på dette ved å kalle den russiske ambassadøren inn på teppet og varsle regelendringer på Svalbard. Forfatterne går langt i å kritisere måten saken ble håndtert på i Norge:

«Sanksjonene er ytterst upopulære i Russland, og ethvert pek mot Vesten faller i god jord hos det russiske publikumet. Attpåtil klarer norske myndigheter å gi ham den reaksjonen og oppmerksomheten han håper på» (s. 66).

At boka er skrevet i kronikkform gjør den tilgjengelig for alle som ønsker å forstå Russland og det bilaterale forholdet mellom Norge og Russland. Som forfatterne selv presiserer betyr dette at deres subjektive meninger kommer tydeligere fram her enn $\mathrm{i}$ en mer akademisk utgivelse. At mange av kronikkene er basert på hverandre og publisert i ulike aviser, fører nødvendigvis til mange gjentakelser. Kronikkene kunne vært bedre redigert i en bokutgivelse.

Det interessante med en slik fremstilling er imidlertid at leseren selv opplever svingningene i naboskapet ved å lese kronikkene kronologisk. Jeg savner likevel et oppsummerende kapittel som tar opp den røde tråden fra 2007 til i dag, og som kommenterer de historiske svingningene vi blir vitne til. Jeg savner også forfatternes refleksjoner rundt atomsamarbeidet og det mellomfolkelige samarbeidet i Barentsregionen, to områder Norge bruker mange millioner kroner på årlig. 
Noen av artiklene inneholder det jeg vil kalle tips til politisk ledelse om hvordan man skal forholde seg til Russland som nabo. Det er akkurat dette som er jobben til forskerne ved FNI; å gi politisk veiledning til hvordan man forholder seg til et naboland som Russland. Det er verdt å merke seg at en av kronikkforfatterne, Jørgen Holten Jørgensen, $\mathrm{i}$ dag er stasjonert som visekonsul ved Det norske generalkonsulatet $\mathrm{i}$ Murmansk - en viktig stasjon for Norge. 